\section{PARULA WARBLER RECORDED NEAR REGINA}

by Alvin Binnie, Regina

A Parula Warbler (Parula americanc.), apparently far off course, came during the fall migration to the grounds of the Provincial Correctional Institution just east of Regina. Credit for the discovery goes to my wife, Mrs. Betty Binnie, who spotted the bird on October 21 and again on the 22nd. On October 23, a group of Regina bird watchers led by veteran observers Lucy Murray and Margaret Belcher, were able to view this warbler rarity at close range over a period of time. Dr. Robert Nero, who has observed Parula Warblers in Minnesota, confirmed the identification when he viewed the bird on the morning of the 24th. It was not seen again.

This sighting of the Parula Warbler is only the fourth record for Saskatchewan and the first since 1959 , when Dr. Bill Gunn recorded the warbler's song at Moose Mountain Provincial Park an June 14 (Blue Jay, 17:114-115). The Parula Warbler was added to the Saskatchewan field check-list of birds, as a straggler, on the strength of Manley Callin's 1956 record from Fort Qu'Appelle (Blue Jay, 14-90-91). The bird at Fort Qu'Appelle was first seen by Callin on May 31, and was photographed by Fred Lahrman of the Saskatchewan Museum of Natural History on June 1. It remained for eight days, being last seen on June 7. The only other known record comes from Enma Lake, where one was seen June 27, 1939 by Farley Mowat and F. Banfield; this record was not published until after Callin's observation and Lahrman's photograph had established the presence of the bird in Saskatchewan (Blue Jay, 16:158). These occurrences must all be regarded as unusual, for the normal breeding range of the Parula Warbler extends "from southeastern Manitoba, central Ontario, southern Quebec, Maine, Prince Edward Island, south to eastern Texas, Louisiana, Missis- sippi, Alabama and central Florida" (Ludlow Griscom and Alexander Sprunt, Jr. 1957. The warblers of America). It is important to note, as Sprunt points out, that the northern subspecies of the Parula Warbler rarely nests anywhere except where the tree lichen, Usnea, "old man's beard" occurs. Since in our northern coniferous forest this lichen is often abundant, there is a possibility that the Parula Warbler nay nest in Saskatchewan.

The Parula Warbler seen at the Provincial Correctional Institution was usually spotted high up in the spruce or top branches of nearby deciduous trees, and it was invariably in the company of Golden-crowned Kinglets and Black-capped and Boreal chickadees which had arrived in migration that same week. There were no other warblers seen in the grounds at this late date.

\section{SCARLET TANAGER IN THE GREAT SANDHILLS}

\section{by Morley Barrett, Saskatoon}

On July 16, 1965, while working on a mule deer research project in the Great Sandhills about 10 miles southwest of Abbey, Saskatchewan, my companion, S. Gatehouse, and myself were surprised to see a Scarlet Tanager (Piranga olivacea). With its brilliant red body and black wing and tail patches we easily identified it as an adult male bird. Even at this date the Scarlet Tanager showed no signs of the forthcoming summer molt and still sported its characteristic breeding colours. The bird did not remain in clear view very long and was soon lost in the hills.

\section{NEST RECORDS}

You are reminded that nest records for the 1965 season should be sent to the Prairie Nest Records Scheme, c/o Robert R. Taylor, Box 1121, Regina. If you need more nest record cards, write to the same address. 